Review

\title{
Zirconia as a Dental Biomaterial
}

\author{
Alvaro Della Bona *, Oscar E. Pecho and Rodrigo Alessandretti \\ Post-graduation Program in Dentistry, Dental School, University of Passo Fundo, Campus I, \\ BR285, Passo Fundo, RS 99052-900, Brazil; E-Mails: opey@correo.ugr.es (O.E.P.), \\ rodrigo.alle@yahoo.com.br (R.A.) \\ * Author to whom correspondence should be addressed; E-Mail: dbona@upf.br; \\ Tel.: +55-54-3316-8395; Fax: +55-54-3316-8409.
}

Academic Editor: Andrew J. Ruys

Received: 24 June 2015 / Accepted: 30 July 2015 / Published: 4 August 2015

\begin{abstract}
Ceramics are very important in the science of dental biomaterials. Among all dental ceramics, zirconia is in evidence as a dental biomaterial and it is the material of choice in contemporary restorative dentistry. Zirconia has been applied as structural material for dental bridges, crowns, inserts, and implants, mostly because of its biocompatibility, high fracture toughness, and radiopacity. However, the clinical success of restorative dentistry has to consider the adhesion to different substrates, which has offered a great challenge to dental zirconia research and development. This study characterizes zirconia as a dental biomaterial, presenting the current consensus and challenges to its dental applications.
\end{abstract}

Keywords: biomaterials; zirconia; bonding

\section{Characteristics of Zirconia}

The most popular dental ceramic systems are silica-, leucite-, lithium disilicate-, alumina-, and zirconia-based materials. Currently, zirconia-based ceramics are the most studied, challenging researches for different reasons.

Zirconia (zirconium dioxide, $\mathrm{ZrO}_{2}$ ), also named as "ceramic steel", has optimum properties for dental use: superior toughness, strength, and fatigue resistance, in addition to excellent wear properties and biocompatibility. 
Zirconium $(\mathrm{Zr})$ is a very strong metal with similar chemical and physical properties to titanium (Ti). Incidentally, $\mathrm{Zr}$ and $\mathrm{Ti}$ are two metals commonly used in implant dentistry, mostly because they do not inhibit the bone forming cells (osteoblasts), which are essential for osseointegration [1].

Dental zirconia is, most often, a modified yttria $\left(\mathrm{Y}_{2} \mathrm{O}_{3}\right)$ tetragonal zirconia polycrystal (Y-TZP). Yttria is added to stabilize the crystal structure transformation during firing at an elevated temperature and improve the physical properties of zirconia. Upon heating, the monoclinic phase of zirconia starts transforming to the tetragonal phase at $1187^{\circ} \mathrm{C}$, peaks at $1197^{\circ} \mathrm{C}$, and finishes at $1206^{\circ} \mathrm{C}$. On cooling, the transformation from the tetragonal to the monoclinic phase starts at $1052{ }^{\circ} \mathrm{C}$, peaks at $1048{ }^{\circ} \mathrm{C}$, and finishes at $1020{ }^{\circ} \mathrm{C}$, exhibiting a hysteresis behavior. The zirconia tetragonal-to-monoclinic phase transformation is known to be a martensitic transformation [2]. During this zirconia phase transformation, the unit cell of monoclinic configuration occupies about $4 \%$ more volume than the tetragonal configuration, which is a relatively large volume change. This could result in the formation of ceramic cracks if no stabilizing oxides were used. Ceria $\left(\mathrm{CeO}_{2}\right)$, yttria $\left(\mathrm{Y}_{2} \mathrm{O}_{3}\right)$, alumina $\left(\mathrm{Al}_{2} \mathrm{O}_{3}\right)$, magnesia $(\mathrm{MgO})$ and calcia $(\mathrm{CaO})$ have been used as stabilizing oxides. So, as the monoclinic phase does not form under normal cooling conditions, the cubic and tetragonal phases are retained, and crack formation, due to phase transformation, is avoided [2]. It is also important to consider that the stabilization of the tetragonal and cubic structures requires different amounts of dopants (stabilizers). The tetragonal phase is stabilized at lower dopant concentrations than the cubic phase. However, another way of stabilizing the tetragonal phase at room temperature is to decrease the crystal size (the critical average grain size is $<0.3 \mu \mathrm{m}$ ) [3]. This effect has been attributed to a surface energy difference [2]. Consequently, zirconia-based ceramics used for biomedical purposes typically exist as a metastable tetragonal partially stabilized zirconia (PSZ) at room temperature. Metastable means that trapped energy still exists within the material to drive it back to the monoclinic phase. It turned out that the highly localized stress ahead of a propagating crack is sufficient to trigger zirconia grains to transform in the vicinity of the crack tip. In this case, the $4 \%$ volume increase becomes beneficial, essentially squeezing the crack to close and increasing toughness, known as transformation toughening [2].

\section{Zirconia Structures for Dentistry}

Zirconia structures used for dental purposes are fabricated using CAD-CAM (computer-aided design and computer-aided manufacturing) technology in two possible ways. One method mills the fully sintered block of zirconia with no distortion (shrinkage) to the final structure. The disadvantages are the great wear of the grinding tools (burs) and the population of flaws produced during the machining that may lower the mechanical reliability of the structure [4,5]. In the other method, the zirconia structure is milled from a pre-sintered block, reaching its final mechanical properties after sintered, which produces structural shrinkage that can be partly compensated at the designing stage, and the fit of the zirconia restoration will be warranted [6,7]. Both CAD-CAM processes have three main steps: acquisition of digital data, computer processing and designing, and fabrication of the zirconia structure [8]. Most importantly, the CAD-CAM technique has the ability to produce zirconia restorations with sufficient precision for dental use $[9,10]$.

Traditionally, zirconia is dull white in color and its opacity can mask the underneath structure. Most dental zirconia systems indicate structural dyeing (coloring) to enhance the esthetic [11]. Currently, 
full-contoured (anatomical-shaped) monolithic zirconia dental restorations are offered [12,13], which could abbreviate or extinguish the dental laboratory work on zirconia-based restorations. Several studies reported, however, that Y-TZP would lose its stability in wet environment, leading to strength degradation mostly because of the crystallographic transformation from metastable tetragonal phase to monoclinic phase (T-M transformation) and inherent cyclic fatigue from chewing and para-functional habits (e.g., bruxism and clenching) [2,6,7,14,15]. Nevertheless, the influence of low temperature degradation (LTD) on dental zirconia is still in need of further investigation.

Even so, the most popular zirconia-based restorations have a zirconia infrastructure that is porcelain veneered to adequate anatomic contour and esthetic. There are two main ways of veneering zirconia infrastructures: the traditional layering technique and the hot pressing method [2,7]. Both methods require some sort of porcelain to zirconia bonding. Some studies have observed an exchange of certain chemical elements at the porcelain-zirconia interface, which may contribute to bonding [7,16], but whether a true chemical bonding has formed is yet to be verified. Therefore, micro-or nano-mechanical interlocking is regarded as the major mechanism of porcelain zirconia bonding [17]. On this basis, and with some dispute, sandblasting the zirconia surface before porcelain veneering or resin bonding appears to be the most popular method to promote mechanical interlocking and most reports recommend moderate pressure (around 0.4 MPa) and small particle size [18,19]. Other studies suggest that sandblasting induces monoclinic phase transformation, but it can be reversed by the veneering process [7,20,21]. In addition, primers and liners have been suggested to improve wetting and bonding to zirconia [2,19,22,23].

Nonetheless, one of the most important reasons for introducing monolithic zirconia restorations is the significant rate of porcelain fracture from porcelain veneered zirconia-based restorations $(6 \%-25 \%$ after three years), which is greater than the fracture rate reported for porcelain fused-to-metal (PFM) systems [2,24-29]. This subject challenged many researchers and triggered few review publications on the fracture rate of all-ceramic restorations [24,27,30], indicating that delamination (failure at porcelain-zirconia interface) and chipping (failure within the veneering porcelain) are the most common modes of failure [30,31]. Studies suggested several possible causes for porcelain failure on zirconia-based restorations [7,15,22,32-36].

The mismatch in some mechanical and thermal properties such as fracture toughness, flexural strength, coefficient of thermal expansion, and elastic modulus affect the bonding between porcelain and zirconia [7,34-38]. One study emphasized the effect of strength misfit on the development of delamination, showing that the mode of failure changes according to the porcelain strength and suggesting the use of veneering material with a high flexural strength (over $300 \mathrm{MPa}$ ) to improve the reliability of zirconia-based restorations [32].

Significant differences on the coefficient of thermal expansion between the zirconia and porcelain influence in the residual stress distribution during the cooling process affecting the reliability of zirconia-based restorations [7,15,22,33-35,38-40]. The veneering porcelain will experience a change from a viscoelastic state to a solid form when its temperature is reduced and when it passes through the glass transition temperature $\left(T_{\mathrm{g}}\right.$ from $480{ }^{\circ} \mathrm{C}$ to $\left.610^{\circ} \mathrm{C}\right)[2,7,40]$. During cooling after sintering, residual stresses might be generated and influence both the strength of porcelain and interfacial integration. Therefore, most manufacturers recommend slow cooling processes [2,38,39].

The initiation and propagation of delamination was also reported to be related to the misfit in elastic moduli and fracture toughness of porcelain and zirconia [36]. 
Pressable veneering porcelains were thought to improve bonding between porcelain and zirconia, but studies are controversial on this matter and most of them showed no significant difference between the traditional and pressing methods $[41,42]$. New veneering methods using CAD-CAM technology seem to improve wetting and bond strength between zirconia and porcelain $[43,44]$.

\section{Resin Bonding to Zirconia}

At first, one could imagine that an all-ceramic restoration would not withstand the intra-oral service. It could be true if the restoration would not be bonded to the tooth structure or remaining restorative materials (e.g., composites and metals), working as an integrated system where diverse stresses, from chewing to para-functional habits (e.g., bruxism), are distributed throughout the system due to appropriate bonding [2,45]. This rationale is supported by the ISO 6872:2010 [46] standard that classifies the ceramics according to the intended clinical use and made the distinction between adhesively and non-adhesively cemented restorations.

Today, glass ionomer (GIC) and resin-based cements are the primary choices for bonding ceramic restorations to the remaining tooth structure. GIC and resin-modified GIC (RMGIC) are often used to cement acid-resistant ceramics, mostly because these cements are very easy to use. However, the most popular and effective cements for all types of ceramic restorations are the resin-based composites, including the systems containing the 10-methacryloyloxydecyl-dihydrogen-phosphate (MDP) monomer [2,45,47].

It has been reported that the clinical success of resin bonding procedures for cementing ceramic restorations and repairing fractured ceramic restorations depends on the quality and durability of the bond. The former depends upon the bonding mechanisms that are controlled in part by the surface treatment that promotes micromechanical and/or chemical bond to the substrate [6,48-58]. The nonreactive surface of zirconia (acid-resistant ceramic), however, presents a consistent issue of poor adhesion, i.e., low bond strength to other substrates [2].

As zirconia is an acid-resistance ceramic, other methods to produce micromechanical retention have been used, including airborne particle abrasion (APA) systems, often called sandblasting, and coarse diamond rotary instruments. Several studies $[17,45,47,50,51,58,59]$ reported that airborne particle abrasion methods using alumina particles or silica-modified alumina particles (silica coating) produced greater surface roughness $\left(R_{\mathrm{a}}\right)$ values and that silica coated surfaces showed a significant increase $(76 \%)$ in the concentration of silicon, which should enhance bonding to resin via silane coupling agents [45,51,59]. Therefore, silica coating (silicatization) systems (e.g., Rocatec and Cojet, 3M-ESPE) have been used to create a silica layer on metal and ceramic surfaces through high-speed surface impact of the silica-modified alumina particles that can penetrate up to $15 \mu \mathrm{m}$ into ceramic and metal substrates. This tribochemical effect may be explained by two bonding mechanisms: (1) the creation of a topographic pattern via airborne particle abrasion allowing for micromechanical bonding to resin; and (2) the promotion of a chemical bond between the silica coated ceramic surface and the resin-based material, via a silane coupling agent $[2,45]$.

Therefore, the adhesion between dental ceramics and resin-based composites is the result of a physico-chemical interaction across the interface between the resin (adhesive) and the ceramic (substrate). The physical contribution to the adhesion process is dependent on the surface treatment and topography of the substrate and can be characterized by its surface energy. Alteration of the surface topography results in changes on the surface area and on the wettability of the substrate, which are related 
to the surface energy and the adhesive potential. In addition, the surface energy of a solid surface is greater than that of its interior where the interatomic distances are equal, and the energy is minimal. In fact, at the surface of the lattice, the energy is greater because the outermost atoms are not equally attracted in all directions. This increase in energy per unit area of surface $\left(\mathrm{J} / \mathrm{m}^{2}\right.$ or $\left.\mathrm{N} / \mathrm{m}\right)$ is referred to as the surface energy $(\gamma)$, or surface tension for liquids (e.g., water: $\gamma=73 \mathrm{~mJ} / \mathrm{m}^{2}$; PTFE- polytetrafluoroethylene: $\gamma=18 \mathrm{~mJ} / \mathrm{m}^{2}$; steel: $\gamma=230 \mathrm{~mJ} / \mathrm{m}^{2}$; liquid resin: $\gamma=40 \mathrm{~mJ} / \mathrm{m}^{2}$ ) $[2,45]$. Therefore, the surface atoms of a solid tend to form bonds to other atoms in close proximity to the surface, reducing the surface energy of the solid. Achieving an energy balance or the lowest energy state is the driving force for the chemical bond between the adhesive and the adherend. However, the surface energy and the adhesive qualities of a given solid can be reduced by any surface impurity or contaminant, such as human secretions and air voids. The functional chemical groups available or the type of crystal plane of a space lattice present at the surface also affect the surface energy $[2,45]$.

Nevertheless, a clean (no contaminants) and dry surface ensures that the adhesive has the best possible chance of creating a proper bond with the adherend. In addition, the wettability of the adherend by the adhesive, the viscosity of the adhesive, and the morphology of adherend surface influence the ability of the adhesive to make intimate contact with the adherend. Thus, to succeed the challenge of resin-bonding to zirconia-based ceramics, one must consider all aspects listed above [2,45]. This rationale has been followed, somehow, in the reports on bonding to zirconia (Table 1). Most experimental procedures that resulted in high bond strength values and had clinical feasibility were tried in vivo. Clinical trials on veneered zirconia-based restorations have showed survival rates of $75 \%-100 \%[28,29,60,61]$, which are similar to other successful restorative procedures.

Table 1. Experimental studies, in chronological order, on resin bonded dental zirconia.

\begin{tabular}{|c|c|c|c|c|c|}
\hline Study & Dental Zirconia & $\begin{array}{c}\text { Aging } \\
\text { (Y, yes; } \\
\text { N, no) }\end{array}$ & $\begin{array}{c}\text { Test } \\
\text { Method }\end{array}$ & $\begin{array}{l}\text { Suggested Bonding } \\
\text { Treatment }\end{array}$ & $\begin{array}{c}\text { Mean Bond } \\
\text { Strength } \\
\text { (MPa) }\end{array}$ \\
\hline $\begin{array}{c}\text { Janda et al., } \\
2003[62]\end{array}$ & Frialit (Degussit) & $\mathrm{Y}$ & shear & $\begin{array}{l}\text { Flame-treated for } 5 \mathrm{~s} / \mathrm{cm}^{2} \\
(\text { PyrosilPen })+\text { silane }\end{array}$ & $16 \pm 6$ \\
\hline $\begin{array}{l}\text { Blatz et al., } \\
2004[63]\end{array}$ & $\begin{array}{c}\text { Procera AllZirkon } \\
\text { (Nobel Biocare) }\end{array}$ & $\mathrm{Y}$ & shear & $\begin{array}{c}\text { APA + adhesive with } \\
\text { MDP + Panavia F }\end{array}$ & $16.8 \pm 3.7$ \\
\hline $\begin{array}{l}\text { Piwowarczyk } \\
\text { et al., } 2005 \text { [64] }\end{array}$ & Lava (3M-Espe) & $\mathrm{Y}$ & shear & Silicatization (Rocatec) & $19.9 \pm 2.6$ \\
\hline $\begin{array}{l}\text { Derand et al., } \\
2005[23]\end{array}$ & $\begin{array}{l}\text { Procera Zirkon } \\
\text { (Nobel Biocare) }\end{array}$ & $\mathrm{N}$ & shear & $\begin{array}{l}\text { Low fusing porcelain } \\
\text { pearls }+ \text { silane }\end{array}$ & $18.4 \pm 3.6$ \\
\hline $\begin{array}{l}\text { Atsu et al., } \\
2006[65]\end{array}$ & Cercon (Dentsply) & $\mathrm{N}$ & shear & $\begin{array}{l}\text { APA + silicatization (Cojet) + } \\
\text { adhesive with MDP + Panavia F }\end{array}$ & $22.9 \pm 3.1$ \\
\hline $\begin{array}{l}\text { Lüthy et al., } \\
2006[66]\end{array}$ & Cercon (Dentsply) & $\mathrm{Y}$ & shear & $\begin{array}{c}\text { Silicatization }(\text { Rocatec })+ \\
\text { Panavia } 21\end{array}$ & $73.8 \pm 8.5$ \\
\hline $\begin{array}{c}\text { Kumbuloglu } \\
\text { et al., } 2006 \text { [67] }\end{array}$ & DCS (Dental AG) & $\mathrm{Y}$ & shear & $\begin{array}{c}\mathrm{APA}+\text { Silicatization }(\text { Rocatec }) \\
+ \text { Panavia } \mathrm{F}\end{array}$ & $20.9 \pm 4.6$ \\
\hline $\begin{array}{c}\text { Blatz et al., } \\
2007[68]\end{array}$ & Lava (3M-Espe) & $\mathrm{Y}$ & shear & $\begin{array}{c}\text { Silicatization }(\text { Rocatec) }+ \\
\text { Panavia F }\end{array}$ & $16.6 \pm 3.2$ \\
\hline $\begin{array}{l}\text { Wolfart et al., } \\
2007 \text { [69] }\end{array}$ & Cercon (Dentsply) & $\mathrm{Y}$ & tensile & $\mathrm{APA}+$ Panavia $\mathrm{F}$ & 39.2 \\
\hline
\end{tabular}


Table 1. Cont.

\begin{tabular}{|c|c|c|c|c|c|}
\hline Study & Dental Zirconia & $\begin{array}{l}\text { Aging } \\
(\mathbf{Y}, \text { yes; } \\
\mathbf{N}, \text { no) } \\
\end{array}$ & $\begin{array}{c}\text { Test } \\
\text { Method }\end{array}$ & $\begin{array}{l}\text { Suggested Bonding } \\
\text { Treatment }\end{array}$ & $\begin{array}{c}\text { Mean Bond } \\
\text { Strength } \\
(\mathrm{MPa}) \\
\end{array}$ \\
\hline $\begin{array}{l}\text { Aboushelib } \\
\text { et al., } 2007 \text { [70] }\end{array}$ & Cercon (Dentsply) & $\mathrm{N}$ & microtensile & $\begin{array}{c}\text { APA + infiltration } \\
\text { etching + Panavia F2.0 }\end{array}$ & $49.8 \pm 2.7$ \\
\hline $\begin{array}{l}\text { Yang et al., } \\
2008[71]\end{array}$ & Cercon (Dentsply) & $\mathrm{Y}$ & tensile & APA + Panavia F2.0 & $29.6 \pm 4.8$ \\
\hline $\begin{array}{l}\text { Aboushelib } \\
\text { et al., 2008 [72] }\end{array}$ & $\begin{array}{l}\text { Procera Zirconia } \\
\text { (Nobel Biocare) }\end{array}$ & $\mathrm{N}$ & microtensile & $\begin{array}{l}\text { infiltration etching + silane } \\
\text { primer + Panavia F2.0 }\end{array}$ & $40.6 \pm 5.8$ \\
\hline $\begin{array}{c}\text { Piascik et al., } \\
2009 \text { [73] }\end{array}$ & $\begin{array}{l}\text { e.max ZirCad } \\
\text { (Ivoclar) }\end{array}$ & $\mathrm{N}$ & microtensile & $\begin{array}{c}\mathrm{APA}+\text { Sílica seed } \\
\text { layer }+ \text { silane }+\mathrm{C} \& \mathrm{~B}\end{array}$ & $23.2 \pm 5.4$ \\
\hline $\begin{array}{c}\text { Cavalcanti } \\
\text { et al., } 2009 \text { [74] }\end{array}$ & Cercon (Dentsply) & $\mathrm{N}$ & microshear & $\begin{array}{l}\text { APA }+ \text { metal primer }+ \\
\text { BisGMA resin cement }\end{array}$ & $27.9 \pm 4.5$ \\
\hline $\begin{array}{l}\text { Heikkinen } \\
\text { et al., } 2009 \text { [75] }\end{array}$ & $\begin{array}{l}\text { Procera Zirconia } \\
\text { (Nobel Biocare) }\end{array}$ & $\mathrm{Y}$ & shear & $\begin{array}{c}\text { Silicatization }(\text { Rocatec) }+ \\
\text { silane }+ \text { resin cement }\end{array}$ & $4.7 \pm 2.7$ \\
\hline $\begin{array}{l}\text { Aboushelib et } \\
\text { al., 2009 [76] }\end{array}$ & $\begin{array}{l}\text { Procera Zirconia } \\
\text { (Nobel Biocare) }\end{array}$ & $\mathrm{N}$ & microtensile & $\begin{array}{l}\text { infiltration etching + silane } \\
\text { primer + Panavia F2.0 }\end{array}$ & $41.0 \pm 5.8$ \\
\hline $\begin{array}{l}\text { Oyagüe et al., } \\
2009 \text { [77] }\end{array}$ & Cercon (Dentsply) & $\mathrm{N}$ & microtensile & $\begin{array}{c}\text { Silicatization }+ \text { resin cement } \\
\text { with MDP }\end{array}$ & $15.3 \pm 3.3$ \\
\hline $\begin{array}{l}\text { Kitayama et al., } \\
\quad 2010[78]\end{array}$ & Cercon (Dentsply) & $\mathrm{N}$ & tensile & $\mathrm{APA}+\mathrm{AZ}$ primer + Resicem & $22.3 \pm 4.6$ \\
\hline $\begin{array}{l}\text { Magne et al., } \\
2010 \text { [79] }\end{array}$ & Lava (3M-Espe) & $\mathrm{N}$ & shear & $\mathrm{APA}+$ primer + Duo-Link & $26.6 \pm 6.2$ \\
\hline $\begin{array}{l}\text { Qeblawi et al., } \\
2010[80]\end{array}$ & $\begin{array}{l}\text { e.max ZirCad } \\
\text { (Ivoclar) }\end{array}$ & Y & shear & $\begin{array}{c}\text { silicatization }+ \text { silane }+ \\
\text { Multilink }\end{array}$ & $30.9 \pm 4.6$ \\
\hline $\begin{array}{l}\text { Jevnikar et al., } \\
2010[81]\end{array}$ & $\begin{array}{c}\text { TZ-3YB-E } \\
\text { Zirconia (Tosoh) }\end{array}$ & Y & shear & $\begin{array}{c}\text { APA }+ \text { alumina coating }+ \\
\text { resin cement }\end{array}$ & $27.3 \pm 3.9$ \\
\hline $\begin{array}{c}\text { Attia } \text { et al. } \\
2011[82]\end{array}$ & $\begin{array}{l}\text { e.max ZirCad } \\
\text { (Ivoclar) }\end{array}$ & Y & tensile & $\begin{array}{c}\text { Silicatization (Rocatec) + } \\
\text { silane + Multilink }\end{array}$ & $39.7 \pm 7.0$ \\
\hline $\begin{array}{l}\text { Matinlinna and } \\
\text { Lassila, } \\
2011 \text { [83] }\end{array}$ & $\begin{array}{c}\text { Procera All Zircon } \\
\text { (Nobel Biocare) }\end{array}$ & Y & shear & $\begin{array}{c}\text { Silicatization }(\text { Rocatec })+ \\
\text { silane }+ \text { resin cement }\end{array}$ & $11.7 \pm 2.3$ \\
\hline $\begin{array}{l}\text { Dias de Souza } \\
\text { et al., } 2011 \text { [84] }\end{array}$ & $\begin{array}{l}\text { Lava Frame } \\
\text { (3M-Espe) }\end{array}$ & $\mathrm{N}$ & microtensile & $\begin{array}{c}\mathrm{APA}+\text { adhesive with MDP + } \\
\text { resin cement }\end{array}$ & $6.1 \pm 5.3$ \\
\hline $\begin{array}{l}\text { de Castro et al., } \\
2012 \text { [85] }\end{array}$ & $\begin{array}{l}\text { In-Ceram YZ } \\
\text { (Vita) }\end{array}$ & $\mathrm{Y}$ & microtensile & $\begin{array}{c}\text { Silicatization }(\text { Cojet })+\text { silane }+ \\
\text { resin cement }\end{array}$ & $13.9 \pm 6.0$ \\
\hline $\begin{array}{l}\text { Lung et al., } \\
2012[86]\end{array}$ & Lava (3M-Espe) & $\mathrm{Y}$ & shear & $\begin{array}{c}\text { Silicatization }(\text { Rocatec) }+ \\
\text { silane }+ \text { resin cement }\end{array}$ & $14.5 \pm 2.2$ \\
\hline $\begin{array}{l}\text { Piascik et al., } \\
2012 \text { [87] }\end{array}$ & Lava (3M-Espe) & $\mathrm{N}$ & shear & $\begin{array}{c}\text { Plasma fluorination }+ \text { resin } \\
\text { cement }\end{array}$ & $37.3 \pm 4.6$ \\
\hline $\begin{array}{l}\text { Chen et al., } \\
2013[88]\end{array}$ & Cercon (Dentsply) & $\mathrm{N}$ & shear & $\begin{array}{l}\mathrm{APA}+\text { primer with } \mathrm{MDP}+ \\
\text { resin cement }\end{array}$ & $29.0 \pm 6.3$ \\
\hline $\begin{array}{c}\text { Karimipour- } \\
\text { Saryazdi et al., } \\
2014 \text { [89] }\end{array}$ & $\begin{array}{l}\text { TZP BIO-HIP } \\
\text { (Metoxit AG) }\end{array}$ & Y & tensile & $\mathrm{APA}+$ resin cement & $3.7 \pm 1.0$ \\
\hline
\end{tabular}


Table 1. Cont.

\begin{tabular}{|c|c|c|c|c|c|}
\hline Study & Dental Zirconia & $\begin{array}{c}\text { Aging } \\
(\mathbf{Y}, \text { yes; } \\
\text { N, no) } \\
\end{array}$ & $\begin{array}{c}\text { Test } \\
\text { Method }\end{array}$ & $\begin{array}{c}\text { Suggested Bonding } \\
\text { Treatment }\end{array}$ & $\begin{array}{c}\text { Mean Bond } \\
\text { Strength } \\
(\mathrm{MPa}) \\
\end{array}$ \\
\hline $\begin{array}{l}\text { Bavbek et al., } \\
2014[90]\end{array}$ & $\begin{array}{l}\text { BruxZir and } \\
\text { Prettau-Zirkon }\end{array}$ & $\mathrm{N}$ & microshear & $\begin{array}{c}\text { Silicatization }(\text { Cojet })+\text { silane }+ \\
\text { resin cement }\end{array}$ & $45.9 \pm 4.8$ \\
\hline $\begin{array}{l}\text { da Silva et al., } \\
2014 \text { [91] }\end{array}$ & $\begin{array}{l}\text { Lava Frame } \\
\text { (3M-Espe) }\end{array}$ & $\mathrm{N}$ & microshear & $\begin{array}{c}\text { Silicatization }(\text { Cojet })+\text { silane }+ \\
\text { resin cement }\end{array}$ & $37.4 \pm 2.3$ \\
\hline $\begin{array}{l}\text { Oba et al., } \\
2014[92]\end{array}$ & $\begin{array}{l}\text { YPS (Kuraray } \\
\text { Noritake) }\end{array}$ & Y & shear & $\begin{array}{l}\text { Silane with MDP (Monobond } \\
\text { Plus) }+ \text { resin cement }\end{array}$ & $7.7 \pm 2.9$ \\
\hline $\begin{array}{l}\text { Pereira et al., } \\
2015[93]\end{array}$ & Lava (3M-Espe) & $\mathrm{N}$ & shear & $\begin{array}{l}\mathrm{APA}+\text { primer with } \mathrm{MDP}+ \\
\text { resin cement }\end{array}$ & $14.1 \pm 6.1$ \\
\hline $\begin{array}{l}\text { Şanlı et al., } \\
2015 \text { [94] }\end{array}$ & $\begin{array}{l}\text { In-Ceram YZ } \\
\text { (Vita) }\end{array}$ & $\mathrm{N}$ & flexural & $\mathrm{APA}+$ resin cement & $50.5 \pm 1.3$ \\
\hline $\begin{array}{l}\text { Kim et al., } \\
\text { 2015a [95] }\end{array}$ & $\begin{array}{l}\text { KZ-3YF AC } \\
(\mathrm{KCM})\end{array}$ & $\mathrm{N}$ & shear & Zirconia primer + resin cement & $10.8 \pm 1.5$ \\
\hline $\begin{array}{l}\text { Abi-Rached } \\
\text { et al., } 2015 \text { [96] }\end{array}$ & Lava (3M-Espe) & $\mathrm{N}$ & shear & $\mathrm{APA}+$ resin cement & $7.7 \pm 1.1$ \\
\hline $\begin{array}{c}\text { Oliveira- } \\
\text { Ogliari et al., } \\
2015 \text { [97] }\end{array}$ & $\begin{array}{l}\text { Zircon-CAD } \\
\text { (Angelus) }\end{array}$ & $\mathrm{N}$ & shear & $\begin{array}{l}\text { Silica coating }+ \text { silane }+ \\
\text { resin cement }\end{array}$ & $36.7 \pm 6.3$ \\
\hline $\begin{array}{l}\text { Lung et al., } \\
2015[98]\end{array}$ & Upcera (Liaoning) & $\mathrm{Y}$ & shear & $\begin{array}{c}\text { Silicatization }(\text { Rocatec) }+ \\
\text { silane }+ \text { resin cement }\end{array}$ & $12.6 \pm 2.2$ \\
\hline $\begin{array}{l}\text { Sciasci et al., } \\
2015[99]\end{array}$ & Lava (3M-Espe) & $\mathrm{N}$ & shear & $\begin{array}{c}\text { Silicatization }(\text { Rocatec) }+ \\
\text { silane + resin cement }\end{array}$ & $14.9 \pm 3.0$ \\
\hline $\begin{array}{l}\text { Qeblawi et al., } \\
2015[100]\end{array}$ & DiaZir (Wieland) & $\mathrm{Y}$ & shear & $\begin{array}{c}\text { Silicatization }(\text { Cojet })+\text { silane }+ \\
\text { resin cement }\end{array}$ & $25.6 \pm 2.9$ \\
\hline $\begin{array}{c}\text { Yi et al., } 2015 \\
{[101]}\end{array}$ & Lava (3M-Espe) & $\mathrm{Y}$ & shear & $\begin{array}{c}\text { APA + Z-prime Plus + } \\
\text { self-adhesive resin cement }\end{array}$ & $16.5 \pm 2.2$ \\
\hline $\begin{array}{l}\text { Kim et al., } \\
\text { 2015b [102] }\end{array}$ & $\begin{array}{l}\text { Cercon Base } \\
\text { (Dentsply) }\end{array}$ & Y & microshear & $\begin{array}{c}\text { Adhesive with MDP + } \\
\text { resin cement }\end{array}$ & $26.9 \pm 6.4$ \\
\hline $\begin{array}{l}\text { Druck et al., } \\
2015 \text { [103] }\end{array}$ & $\begin{array}{l}\text { In-Ceram YZ } \\
\text { (Vita) }\end{array}$ & $\mathrm{Y}$ & shear & $\begin{array}{l}\text { Silicatization }+ \text { silane }+ \\
\text { resin cement }\end{array}$ & $9.1 \pm 4.4$ \\
\hline
\end{tabular}

APA-Airborne particle abrasion (sandblasting); water storage was not considered as an aging process.

Considering the in vitro studies (Table 1) and the clinical trials, the two most popular clinical strategies to resin bond acid-resistant ceramic restorations are $[2,45]$ :

1. Improving mechanical retention with APA using alumina particles associated to a chemical bonding mechanism using an adhesive/cement system containing ceramic primers, such as phosphate-based monomers, e.g., MDP.

2. Improving mechanical retention with APA using silica-coated alumina particles to introduce an irregular silica layer onto the ceramic surface followed by a silane coupling agent, which promotes a chemical bond to any resin-based adhesive/cement system.

Nevertheless, manufacturers routinely provide cementation recommendations that should be given serious consideration. 
However, dental ceramics are, inherently, brittle and can fracture. In general, the most common causes of all-ceramic structural failures are (1) fracture initiated in the connector area of fixed partial dentures (FPDs), either at the core-veneer interface or at the gingival embrasure; and (2) chipping of the porcelain veneer $[2,6,24,38,60,104-107]$.

The mode of failure is an important aspect of bond strength tests, but it is not commonly reported. A detailed inspection of the fractured surfaces can indicate the failure mode of a bonded assembly. The fracture behavior of adhesive interfaces depends on the stress level, the flaw distribution, material properties, and environmental effects. Therefore, fracture surface characterization combined with analyses of fracture mechanics parameters are of great importance to understand and predict bonded interface reliability and also to reduce the risk for data misinterpretation such as the inference that the bond strength exceed the cohesive strength of the substrate when the fracture initiates away from the interface $[2,45,47,51,55]$. Therefore, failure analysis based on fractographic principles should assist researchers to correctly interpret the fracture phenomena $[2,45,47,55,108-111]$, avoiding simplistic comments such as "mixed mode of failure". Thus, when fractography is correctly used to determine the fracture origin, a proper scientific statement on the mode of fracture can be formulated, improving the quality of the scientific report [2].

The above rationale on adhesion to zirconia should develop the fundamental basis to understand the clinical performance of bonded zirconia-based restorations, the possible failure causes, and the principles to improve the adhesion mechanisms of resin-based composite bonded to zirconia.

\section{Acknowledgments}

This study was partially supported by CNPq do Brasil grant \# 304995/2013-4, PNPD 42009014007P4 from CAPES (Coordenação de Aperfeiçoamento de Pessoal de Nível Superior) do Brasil, and 396-2551/14-1 from FAPERGS (Fundação de Amparo à Pesquisa do Estado do Rio Grande do Sul) scholarships.

\section{Author Contributions}

The first author is the main author. The article was written and edited by Alvaro Della Bona, Oscar E. Pecho and Rodrigo Alessandretti.

\section{Conflicts of Interest}

The authors declare no conflict of interest

\section{References}

1. Kobayashi, E.; Matsumoto, S.; Doi, H.; Yoneyama, T.; Hamanaka, H. Mechanical properties of the binary titanium-zirconium alloys and their potential for biomedical materials. J. Biomed. Mater. Res. 1995, 29, 943-950.

2. Della Bona, A. Bonding to Ceramics: Scientific Evidences for Clinical Dentistry; Artes Medicas: Sao Paulo, Brazil, 2009.

3. Becher, P.F.; Swain, M.V. Grain-size-dependent transformation behavior in polycrystalline tetragonal zirconia. J. Am. Ceram. Soc. 1992, 75, 493-502. 
4. Luthardt, R.G.; Holzhüter, M.; Sandkuhl, O.; Herold, V.; Schnapp, J.D.; Kuhlisch, E.; Walter, M. Reliability and properties of ground Y-TZP-zirconia ceramics. J. Dent. Res. 2002, 81, 487-491.

5. Corazza, P.H.; de Castro, H.L.; Feitosa, S.A.; Kimpara, E.T.; Della Bona, A. Influence of CAD-CAM diamond bur deterioration on surface roughness and maximum failure load of Y-TZP-based restorations. Am. J. Dent. 2015, 28, 95-99.

6. Denry, I.; Kelly, J.R. State of the art of zirconia for dental applications. Dent. Mater. 2008, 24, 299-307.

7. Liu, D.; Matinlinna, J.P.; Pow, E.H.N. Insights into porcelain zirconia bonding. J. Adhes. Sci. Technol. 2012, 26, 1249-1265.

8. Coli, P.; Karlsson, S. Precision of a CAD/CAM technique for the production of zirconium dioxide copings. Int. J. Prosthodont. 2004, 17, 577-580.

9. Abduo, J.; Lyons, K.; Swain, M. Fit of zirconia fixed partial denture: A systematic review. J. Oral Rehabil. 2010, 37, 866-876.

10. Boitelle, P.; Mawussi, B.; Tapie, L.; Fromentin, O. A systematic review of CAD/CAM fit restoration evaluations. J. Oral Rehabil. 2014, 41, 853-874.

11. Hjerppe, J.; Närhi, T.; Fröberg, K.; Vallittu, P.K.; Lassila, L.V. Effect of shading the zirconia framework on biaxial strength and surface microhardness. Acta Odontol. Scand. 2008, 66, 262-267.

12. Batson, E.R.; Cooper, L.F.; Duqum, I.; Mendonça, G. Clinical outcomes of three different crown systems with CAD/CAM technology. J. Prosthet. Dent. 2014, 112, 770-777.

13. Sun, T.; Zhou, S.; Lai, R.; Liu, R.; Ma, S.; Zhou, Z.; Longquan, S. Load-bearing capacity and the recommended thickness of dental monolithic zirconia single crowns. J. Mech. Behav. Biomed. Mater. 2014, 35, 93-101.

14. Piconi, C.; Maccauro, G. Zirconia as a ceramic biomaterial. Biomaterials 1999, 20, 1-25.

15. Swain, M.V. Unstable cracking (chipping) of veneering porcelain on all-ceramic dental crowns and fixed partial dentures. Acta Biomater. 2009, 5, 1668-1677.

16. Kawai, Y.; Uo, M.; Watari, F. Microstructure evaluation of the interface between dental zirconia ceramics and veneering porcelain. Nano Biomed. 2010, 2, 31-36.

17. Queiroz, J.R.; Benetti, P.; Massi, M.; Junior, L.N.; Della Bona, A. Effect of multiple firing and silica deposition on the zirconia-porcelain interfacial bond strength. Dent. Mater. 2012, 28, 763-768.

18. Nakamura, T.; Wakabayashi, K.; Zaima, C.; Nishida, H.; Kinuta, S.; Yatani, H. Tensile bond strength between tooth-colored porcelain and sandblasted zirconia framework. J. Prosthodont. Res. 2009, 53, 116-119.

19. Kern, M. Bonding to oxide ceramics-laboratory testing versus clinical outcome. Dent. Mater. 2015, 31, 8-14.

20. Guazzato, M.; Quach, L.; Albakry, M.; Swain, M.V. Influence of surface and heat treatments on the flexural strength of Y-TZP dental ceramic. J. Dent. 2005, 33, 9-18.

21. De Kler, M.; de Jager, N.; Meegdes, M.; van der Zel, J.M. Influence of thermal expansion mismatch and fatigue loading on phase changes in porcelain veneered Y-TZP zirconia discs. J. Oral Rehabil. 2007, 34, 841-847.

22. Aboushelib, M.N.; de Jager, N.; Kleverlaan, C.J.; Feilzer, A.J. Microtensile bond strength of different components of core veneered all-ceramic restorations. Dent. Mater. 2005, 21, 984-991. 
23. Derand, T.; Molin, M.; Kvam, K. Bond strength of composite luting cement to zirconia ceramic surfaces. Dent. Mater. 2005, 21, 1158-1162.

24. Della Bona, A.; Kelly, J.R. The clinical success of all-ceramic restorations. J. Am. Dent. Assoc. 2008, 139, S8-S13.

25. Della Bona, A.; Kelly, J.R. A variety of patient factors may influence porcelain veneer survival over a 10-year period. J. Evid. Based Dent. Pract. 2010, 10, 35-36.

26. Vult von Steyern, P.; Carlson, P.; Nilner, K. All-ceramic fixed partial dentures designed according to the DC-Zirkon technique. A 2-year clinical study. J. Oral Rehabil. 2005, 32, 180-187.

27. Sailer, I.; Pjetursson, B.E.; Zwahlen, M.; Hämmerle, C.H. A systematic review of the survival and complication rates of all-ceramic and metal-ceramic reconstructions after an observation period of at least 3 years. Part II: Fixed dental prostheses. Clin. Oral Implants Res. 2007, 18, 86-96.

28. Tinschert, J.; Schulze, K.A.; Natt, G.; Latzke, P.; Heussen, N.; Spiekermann, H. Clinical behavior of zirconia-based fixed partial dentures made of DC-Zirkon: 3-year results. Int. J. Prosthodont. 2008, 21, 217-222.

29. Sailer, I.; Gottnerb, J.; Kanelb, S.; Hammerle, C.H. Randomized controlled clinical trial of zirconia-ceramic and metal-ceramic posterior fixed dental prostheses: A 3-year follow-up. Int. J. Prosthodont. 2009, 22, 553-560.

30. Al-Amleh, B.; Lyons, K.; Swain, M. Clinical trials in zirconia: A systematic review. J. Oral Rehabil. 2010, 37, 641-652.

31. Deng, Y.; Lawn, B.R.; Lloyd, I.K. Characterization of damage modes in dental ceramic bilayer structures. J. Biomed. Mater. Res. 2002, 63, 137-145.

32. Liu, Y.; Feng, H.; Bao, Y.; Qiu, Y.; Xing, N.; Shen, Z. Fracture and interfacial delamination origins of bilayered ceramic composites for dental restorations. J. Eur. Ceram. Soc. 2010, 30, 1297-1305.

33. Saito, A.; Komine, F.; Blatz, M.B.; Matsumura, H. A comparison of bond strength of layered veneering porcelains to zirconia and metal. J. Prosthet. Dent. 2010, 104, 247-257.

34. Aboushelib, M.N.; Feilzer, A.J.; de Jager, N.; Kleverlaan, C.J. Prestresses in bilayered all-ceramic restorations. J. Biomed. Mater. Res. B Appl. Biomater. 2008, 87, 139-145.

35. Fischer, J.; Stawarzcyk, B.; Trottmann, A.; Hämmerle, C.H. Impact of thermal misfit on shear strength of veneering ceramic/zirconia composites. Dent. Mater. 2009, 25, 419-423.

36. Guazzato, M.; Proos, K.; Quach, L.; Swain, M.V. Strength, reliability and mode of fracture of bilayered porcelain/zirconia (Y-TZP) dental ceramics. Biomaterials 2004, 25, 5045-5052.

37. Aboushelib, M.N.; Kleverlaan, C.J.; Feilzer, A.J. Effect of zirconia type on its bond strength with different veneer ceramics. J. Prosthodont. 2008, 17, 401-408.

38. Benetti, P.; Della Bona, A.; Kelly, J.R. Evaluation of thermal compatibility between core and veneer dental ceramics using shear bond strength test and contact angle measurement. Dent. Mater. 2010, 26, 743-750.

39. Taskonak, B.; Mecholsky, J.J.; Anusavice, K.J. Residual stresses in bilayer dental ceramics. Biomaterials 2005, 26, 3235-3241.

40. Taskonak, B.; Borges, G.A.; Mecholsky, J.J.; Anusavice, K.J.; Moore, B.K.; Yan, J. The effects of viscoelastic parameters on residual stress development in a zirconia/glass bilayer dental ceramic. Dent. Mater. 2008, 24, 1149-1155. 
41. Guess, P.C.; Zhang, Y.; Thompson, V.P. Effect of veneering techniques on damage and reliability of Y-TZP trilayers. Eur. J. Esthet. Dent. 2009, 4, 262-276.

42. Aboushelib, M.N.; Kleverlaan, C.J.; Feilzer, A.J. Microtensile bond strength of different components of core veneered all-ceramic restorations. Part 3: Double veneer technique. J. Prosthodont. 2008, 17, 9-13.

43. Aboushelib, M.N.; de Kler, M.; van der Zel, J.M.; Feilzer, A.J. Effect of veneering method on the fracture and bond strength of bilayered zirconia restorations. Int. J. Prosthodont. 2008, 21, 237-240.

44. Renda, J.J.; Harding, A.B.; Bailey, C.W.; Guillory, V.L.; Vandewalle, K.S. Microtensile bond strength of lithium disilicate to zirconia with the CAD-on technique. J. Prosthodont. 2015, 24, 188-193.

45. Della Bona, A.; Borba, M.; Benetti, P.; Pecho, O.E.; Alessandretti, R.; Mosele, J.C.; Mores, R.T. Adhesion to dental ceramics. Curr. Oral Health Rep. 2014, 1, 232-238.

46. ISO 6872:2010 Dental Ceramics, 3rd ed.; International Organization of Standardization (ISO): Geneva, Switzerland, 2010.

47. Della Bona, A. Important aspects of bonding resin to dental ceramics. J. Adhes. Sci. Technol. 2009, 23, 1163-1176.

48. Della Bona, A.; Anusavice, K.J. Microstructure, composition, and etching topography of dental ceramics. Int. J. Prosthodont. 2002, 15, 159-167.

49. Della Bona, A.; Anusavice, K.J.; Hood, J.A. Effect of ceramic surface treatment on tensile bond strength to a resin cement. Int. J. Prosthodont. 2002, 15, 248-253.

50. Della Bona, A.; Donassollo, T.A.; Demarco, F.F.; Barrett, A.A.; Mecholsky, J.J. Characterization and surface treatment effects on topography of a glass-infiltrated alumina/zirconia-reinforced ceramic. Dent. Mater. 2007, 23, 769-775.

51. Della Bona, A.; Borba, M.; Benetti, P.; Cecchetti, D. Effect of surface treatments on the bond strength of a zirconia-reinforced ceramic to composite resin. Braz. Oral. Res. 2007, 21, 10-15.

52. Van Noort, R.; Noroozi, S.; Howard, I.C.; Cardew, G. A critique of bond strength measurements. J. Dent. 1989, 17, 61-67.

53. Boscato, N.; Della Bona, A.; Del Bel Cury, A.A. Influence of ceramic pre-treatments on tensile bond strength and mode of failure of resin bonded to ceramics. Am. J. Dent. 2007, 20, 103-108.

54. Della Bona, A.; van Noort, R. Shear vs. tensile bond strength of resin composite bonded to ceramic. J. Dent. Res. 1995, 74, 1591-1596.

55. Della Bona, A.; Anusavice, K.J.; Shen, C. Microtensile strength of composite bonded to hot-pressed ceramics. J. Adhes. Dent. 2000, 2, 305-313.

56. Della Bona, A.; Anusavice, K.J.; Mecholsky, J.J. Failure analysis of resin composite bonded to ceramic. Dent. Mater. 2003, 19, 693-699.

57. Della Bona, A.; Shen, C.; Anusavice, K.J. Work of adhesion of resin on treated lithia disilicate-based ceramic. Dent. Mater. 2004, 20, 338-344.

58. Della Bona, A.; Anusavice, K.J.; Mecholsky, J.J. Apparent interfacial fracture toughness of resin/ceramic systems. J. Dent. Res. 2006, 85, 1037-1041.

59. Lung, C.Y.; Matinlinna, J.P. Aspects of silane coupling agents and surface conditioning in dentistry: An overview. Dent. Mater. 2012, 28, 467-477. 
60. Christensen, R.P.; Ploeger, B.J. A clinical comparison of zirconia, metal and alumina fixed-prosthesis frameworks veneered with layered or pressed ceramic: A three-year report. J. Am. Dent. Assoc. 2010, 141, 1317-1329.

61. Sailer, I.; Fehér, A.; Filser, F.; Gauckler, L.J.; Lüthy, H.; Hämmerle, C.H. Five-year clinical results of zirconia frameworks for posterior fixed partial dentures. Int. J. Prosthodont. 2007, 20, 383-388.

62. Janda, R.; Roulet, J.F.; Wulf, M.; Tiller, H.J. A new adhesive technology for all-ceramics. Dent. Mater. 2003, 19, 567-573.

63. Blatz, M.B.; Sadan, A.; Martin, J.; Lang, B. In vitro evaluation of shear bond strengths of resin to densely-sintered high-purity zirconium-oxide ceramic after long-term storage and thermal cycling. J. Prosthet. Dent. 2004, 91, 356-362.

64. Piwowarczyk, A.; Lauer, H.C.; Sorensen, J.A. The shear bond strength between luting cements and zirconia ceramics after two pre-treatments. Oper. Dent. 2005, 30, 382-388.

65. Atsu, S.S.; Kilicarslan, M.A.; Kucukesmen, H.C.; Aka, P.S. Effect of zirconium-oxide ceramic surface treatments on the bond strength to adhesive resin. J. Prosthet. Dent. 2006, 95, 430-436.

66. Lüthy, H.; Loeffel, O.; Hammerle, C.H. Effect of thermocycling on bond strength of luting cements to zirconia ceramic. Dent. Mater. 2006, 22, 195-200.

67. Kumbuloglu, O.; Lassila, L.V.; User, A.; Vallittu, P.K. Bonding of resin composite luting cements to zirconium oxide by two air-particle abrasion methods. Oper. Dent. 2006, 31, 248-255.

68. Blatz, M.B.; Chiche, G.; Holst, S.; Sadan, A. Influence of surface treatment and simulated aging on bond strengths of luting agents to zirconia. Quintessence Int. 2007, 38, 745-753.

69. Wolfart, M.; Lehmann, F.; Wolfart, S.; Kern, M. Durability of the resin bond strength to zirconia ceramic after using different surface conditioning methods. Dent. Mater. 2007, 23, 45-50.

70. Aboushelib, M.N.; Kleverlaan, C.J.; Feilzer, A.J. Selective infiltration-etching technique for a strong and durable bond of resin cements to zirconia-based materials. J. Prosthet. Dent. 2007, 98, 379-388.

71. Yang, B.; Lange-Jansen, H.C.; Scharnberg, M.; Wolfart, S.; Ludwig, K.; Adelung, R.; Kern, M. Influence of saliva contamination on zirconia ceramic bonding. Dent. Mater. 2008, 24, 508-513.

72. Aboushelib, M.N.; Matinlinna, J.P.; Salameh, Z.; Ounsi, H. Innovations in bonding to zirconia-based materials: Part I. Dent. Mater. 2008, 24, 1268-1272.

73. Piascik, J.R.; Swift, E.J.; Thompson, J.Y.; Grego, S.; Stoner, B.R. Surface modification for enhanced silanation of zirconia ceramics. Dent. Mater. 2009, 25, 1116-1121.

74. Cavalcanti, A.N.; Foxton, R.M.; Watson, T.F.; Oliveira, M.T.; Giannini, M.; Marchi, G.M. Bond strength of resin cements to a zirconia ceramic with different surface treatments. Oper. Dent. 2009, 34, 280-287.

75. Heikkinen, T.T.; Lassila, L.V.J.; Martinlinna, J.P.; Vallittu, P.K. Thermocycling effects on resin bond to silicatized and silanized zirconia. J. Adhes. Sci. Technol. 2009, 23, 1043-1051.

76. Aboushelib, M.N.; Mirmohamadi, H.; Matinlinna, J.P.; Kukk, E.; Ounsi, H.F.; Salameh, Z. Innovations in bonding to zirconia-based materials. Part II: Focusing on chemical interactions. Dent. Mater. 2009, 25, 989-993.

77. Oyagüe, R.C.; Monticelli, F.; Toledano, M.; Osorio, E.; Ferrari, M.; Osorio, R. Effect of water aging on microtensile bond strength of dual-cured resin cements to pre-treated sintered zirconiumoxide ceramics. Dent. Mater. 2009, 25, 392-399. 
78. Kitayama, S.; Nikaido, T.; Takahashi, R.; Zhu, L.; Ikeda, M.; Foxton, R.M.; Sadr, A.; Tagami, J. Effect of primer treatment on bonding of resin cements to zirconia ceramic. Dent. Mater. 2010, 26, 426-432.

79. Magne, P.; Paranhos, M.P.; Burnett, L.H. New zirconia primer improves bond strength of resin-based cements. Dent. Mater. 2010, 26, 345-352.

80. Qeblawi, D.M.; Muñoz, C.A.; Brewer, J.D.; Monaco, E.A. The effect of zirconia surface treatment on flexural strength and shear bond strength to a resin cement. J. Prosthet. Dent. 2010, 103, $210-220$.

81. Jevnikar, P.; Krnel, K.; Kocjan, A.; Funduk, N.; Kosmac, T. The effect of nano-structured alumina coating on resin-bond strength to zirconia ceramics. Dent. Mater. 2010, 26, 688-696.

82. Attia, A.; Lehmann, F.; Kern, M. Influence of surface conditioning and cleaning methods on resin bonding to zirconia ceramic. Dent. Mater. 2011, 27, 207-213.

83. Matinlinna, J.P.; Lassila, L.V. Enhanced resin-composite bonding to zirconia framework after pretreatment with selected silane monomers. Dent. Mater. 2011, 27, 273-280.

84. Dias de Souza, G.M.; Thompson, V.P.; Braga, R.R. Effect of metal primers on microtensile bond strength between zirconia and resin cements. J. Prosthet. Dent. 2011, 105, 296-303.

85. De Castro, H.L.; Corazza, P.H.; Paes-Júnior, T.de.A.; Della Bona, A. Influence of Y-TZP ceramic treatment and different resin cements on bond strength to dentin. Dent. Mater. 2012, 28, 1191-1197.

86. Lung, C.Y.; Botelho, M.G.; Heinonen, M.; Matinlinna, J.P. Resin zirconia bonding promotion with some novel coupling agents. Dent. Mater. 2012, 28, 863-872.

87. Piascik, J.R.; Swift, E.J.; Braswell, K.; Stoner, B.R. Surface fluorination of zirconia: Adhesive bond strength comparison to commercial primers. Dent. Mater. 2012, 28, 604-608.

88. Chen, L.; Shen, H.; Suh, B.I. Effect of incorporating BisGMA resin on the bonding properties of silane and zirconia primers. J. Prosthet. Dent. 2013, 110, 402-407.

89. Karimipour-Saryazdi, M.; Sadid-Zadeh, R.; Givan, D.; Burgess, J.O.; Ramp, L.C.; Liu, P.R. Influence of surface treatment of yttrium-stabilized tetragonal zirconium oxides and cement type on crown retention after artificial aging. J. Prosthet. Dent. 2014, 111, 395-403.

90. Bavbek, N.C.; Roulet, J.F.; Ozcan, M. Evaluation of microshear bond strength of orthodontic resin cement to monolithic zirconium oxide as a function of surface conditioning method. J. Adhes. Dent. 2014, 16, 473-480.

91. da Silva, E.M.; Miragaya, L.; Sabrosa, C.E.; Maia, L.C. Stability of the bond between two resin cements and an yttria-stabilized zirconia ceramic after six months of aging in water. J. Prosthet. Dent. 2014, 112, 568-575.

92. Oba, Y.; Koizumi, H.; Nakayama, D.; Ishii, T.; Akazawa, N.; Matsumura, H. Effect of silane and phosphate primers on the adhesive performance of a tri-n-butylborane initiated luting agent bonded to zirconia. Dent. Mater. J. 2014, 33, 226-232.

93. Pereira, L.L.; Campos, F.; Dal Piva, A.M.; Gondim, L.D.; Souza, R.O.; Özcan, M. Can application of universal primers alone be a substitute for airborne-particle abrasion to improve adhesion of resin cement to zirconia? J. Adhes. Dent. 2015, 17, 169-174.

94. Şanlı, S.; Çömlekoğlu, M.D.; Çömlekoğlu, E.; Sonugelen, M.; Pamir, T.; Darvell, B.W. Influence of surface treatment on the resin-bonding of zirconia. Dent. Mater. 2015, 31, 657-668. 
95. Kim, G.H.; Park, S.W.; Lee, K.; Oh, G.J.; Lim, H.P. Shear bond strength between resin cement and colored zirconia made with metal chlorides. J. Prosthet. Dent. 2015, 113, 603-608.

96. Abi-Rached, F.O.; Martins, S.B.; Almeida-Júnior, A.A.; Adabo, G.L.; Góes, M.S.; Fonseca, R.G. Air abrasion before and/or after zirconia sintering: Surface characterization, flexural strength, and resin cement bond strength. Oper. Dent. 2015, 40, E66-E75.

97. Oliveira-Ogliari, A.; Collares, F.M.; Feitosa, V.P.; Sauro, S.; Ogliari, F.A.; Moraes, R.R. Methacrylate bonding to zirconia by in situ silica nanoparticle surface deposition. Dent. Mater. 2015, 31, 68-76.

98. Lung, C.Y.; Liu, D.; Matinlinna, J.P. Silica coating of zirconia by silicon nitride hydrolysis on adhesion promotion of resin to zirconia. Mater. Sci. Eng. C Mater. Biol. Appl. 2015, 46, 103-110.

99. Sciasci, P.; Abi-Rached, F.O.; Adabo, G.L.; Baldissara, P.; Fonseca, R.G. Effect of surface treatments on the shear bond strength of luting cements to Y-TZP ceramic. J. Prosthet. Dent. 2015, $113,212-219$.

100. Qeblawi, D.M.; Campillo-Funollet, M.; Muñoz, C.A. In vitro shear bond strength of two self-adhesive resin cements to zirconia. J. Prosthet. Dent. 2015, 113, 122-127.

101. Yi, Y.A.; Ahn, J.S.; Park, Y.J.; Jun, S.H.; Lee, I.B.; Cho, B.H.; Son, H.H.; Seo, D.G. The effect of sandblasting and different primers on shear bond strength between yttria-tetragonal zirconia polycrystal ceramic and a self-adhesive resin cement. Oper. Dent. 2015, 40, 63-71.

102. Kim, J.H.; Chae, S.Y.; Lee, Y.; Han, G.J.; Cho, B.H. Effects of multipurpose, universal adhesives on resin bonding to zirconia ceramic. Oper. Dent. 2015, 40, 55-62.

103. Druck, C.C.; Pozzobon, J.L.; Callegari, G.L.; Dorneles, L.S.; Valandro, L.F. Adhesion to Y-TZP ceramic: Study of silica nanofilm coating on the surface of Y-TZP. J. Biomed. Mater. Res. B Appl. Biomater. 2015, 103, 143-150.

104. Borba, M.; de Araújo, M.D.; Fukushima, K.A.; Yoshimura, H.N.; Cesar, P.F.; Griggs, J.A.; Della Bona, A. Effect of the microstructure on the lifetime of dental ceramics. Dent. Mater. 2011, 27, 710-721.

105. Kelly, J.R. Dental ceramics: Current thinking and trends. Dent. Clin. N. Am. 2004, 48, 513-530.

106. Kelly, J.R.; Denry, I. Stabilized zirconia as a structural ceramic: An overview. Dent. Mater. 2008, 24, 289-298.

107. Rekow, E.D.; Harsono, M.; Janal, M.; Thompson, V.P.; Zhang, G. Factorial analysis of variables influencing stress in all-ceramic crowns. Dent. Mater. 2006, 22, 125-132.

108. Kelly, J.R.; Benetti, P.; Rungruanganunt, P.; Bona, A.D. The slippery slope: Critical perspectives on in vitro research methodologies. Dent. Mater. 2012, 28, 41-51.

109. Quinn, G.D. Fractography of Ceramics and Glasses; National Institute of Standards and Technology (NIST): Gaithersburg, MD, USA, 2007.

110. Borba, M.; de Araújo, M.D.; de Lima, E.; Yoshimura, H.N.; Cesar, P.F.; Griggs, J.A.; Della Bona, A. Flexural strength and failure modes of layered ceramic structures. Dent. Mater. 2011, 27, 1259-1266.

111. Della Bona, A.; Mecholsky, J.J.; Anusavice, K.J. Fracture behavior of lithia disilicate- and leucite-based ceramics. Dent. Mater. 2004, 20, 956-962.

(C) 2015 by the authors; licensee MDPI, Basel, Switzerland. This article is an open access article distributed under the terms and conditions of the Creative Commons Attribution license (http://creativecommons.org/licenses/by/4.0/). 